\title{
A REVIEW OF SPIRITUAL REMINISCENCE THERAPY FOR OLDER PEOPLE WITH MENTAL HEALTH PROBLEMS
}

\author{
Sharifah Munirah Syed Elias* \\ Department of Special Care Nursing, Kulliyyah of Nursing, International Islamic University Malaysia
}

\begin{abstract}
Spiritual reminiscence therapy (SRT) is an intervention that involves evaluation of life experiences by sharing memories with others that guide individuals to understand the purpose of their life and future hopes. The effectiveness of SRT more specifically for older people needs greater interrogation before this intervention can be recommended. An integrative review of the literature was conducted to explore this question. The search involved published and unpublished studies using the keywords: spiritual reminiscence OR spiritual life review OR religious life review OR spiritual therapies AND older people OR older adults. The search strategy resulted in 847 studies from the electronic databases. Of the 847 studies, five met the inclusion criteria. Out of these five studies, three were quantitative studies, and two were qualitative studies. The evidence regarding the effectiveness of SRT was limited. Despite limited evidence from the quantitative findings, the qualitative findings suggested that SRT can be a worthwhile intervention for older people. Therefore, there is a need in future research to further understand SRT as an intervention for older people.
\end{abstract}

Keywords: spiritual reminiscence therapy, reminiscence therapy, older people

\section{Introduction}

Loneliness, anxiety, and depression are serious mental health problems among older people. Pharmacological intervention is often a first-line approach to treat clinically diagnosed anxiety (Flint, 2005) and depression (Wilson et al., 2001) in older people. Although pharmacological intervention has been found to be effective for older people with anxiety and depression, this treatment may not be the best option because it causes various adverse effects (Coupland et al., 2011) such as risk of falls (Frazer et al., 2005) and risk of orthostatic hypotension associated with factures (Lindsey, 2009). Further, loneliness is not a condition that requires pharmacological interventions.

Given the serious issues related to medication, non-pharmacological interventions may be more appropriate for older people with loneliness, anxiety and depression. One of the useful intervention is reminiscence therapy (RT). RT uses the recall of past events, feelings and thoughts to facilitate pleasure, quality of life or adaptation to current circumstances (Bulechek et al., 2008). RT need to be adapted for the Malaysian population because this population is highly influenced by cultural practices, many of which are based in religious traditions. Webster et al. (2010) pointed to the importance of cultural integration in RT, as cultural beliefs may influence the acceptability of the program content. Furthermore, the adaptation process is essential because RT involves the recall of memories that strongly relate to cultural values (Conway and Pleydell-Pearce, 2000, Harris, 1997).

For the Malaysian population, cultural practices are intertwined with religious practices (Haque, 2008). Islam is the main religion of Malaysia, and Malay culture is highly influenced by Islamic practice (Haque, 2008). In Islam, religious practices include prayers, reciting the Qur'an and practising good deeds (Ibrahim, 2014). Chinese cultural practice is related to Buddhism, in which religious practice is focused on behaviours that promote love and care through a relationship with people and their surroundings (Ibrahim, 2014). Indian cultural practice is related to Hinduism, in which the expression of religiosity is through prayers, meditation, Mantra (spiritual singing) and yoga that are performed as individuals or in groups (Ibrahim, 2014). The centrality of 
religious values to cultural practices suggests that incorporating an understanding of religious identity is an important part of adaptation to a Malaysian population.

The integration of cultural and religious practices in RT may also increase the acceptability of this intervention for this population. In the study conducted by Muhamad and Merriam (2000) in Malaysia, older people reported that they were more interested in joining activities that involved religious and spiritual values compared to activities that focused on personal or material values. Their study included 19 older people aged 60 years and older with various religions: Islam, Christianity, Hinduism and Buddhism. These older people were in favour of religious and spiritual interventions that assisted them to find purpose of their life (Muhamad and Merriam, 2000). Further, a qualitative study that involved 20 older people living in residential aged care facilities (RACFs) in Malaysia found that activities with a religious component improved feelings of wellbeing (Syed Akil and Abdullah, 2015). In a more recent study, Razali et al. (2002) investigated the effect of religiouscultural values in psychotherapy compared to a control group (received standard treatment for anxiety) among 165 Malaysian people with anxiety. The enhanced psychotherapy showed significant improvement in anxiety compared with those in the control group. These studies demonstrate the significance of religious integration into therapeutic approaches for older people in Malaysia.

Religiosity and spirituality are separate but interrelated constructs, despite occasionally being interpreted as identical (Koenig et al., 2012). Spirituality is the interaction between oneself and the environment, religion, family and nature (MacKinlay and Trevitt, 2006, MacKinlay and Trevitt, 2012). Religion is therefore one component of spirituality. Spirituality has been shown to have benefits for older people. One of the advantages of spirituality is it can be a protective agent and provide support (Abolfathi Momtaz et al., 2012, Han and Richardson, 2010), offering healing action towards mental health (Haque, 2008). In particular, for loneliness, anxiety and depression, spirituality acts as a buffer through a more positive outlook and coping strategies (Amzat and Jayawardena, 2016, Koenig et al., 2001). Spirituality has also been reported to serve as a coping mechanism among older people with anxiety (Stanley et al., 2011), and reduce the strength of the relationship between chronic diseases and depression among 1415 older Malay Muslims (Abolfathi Momtaz et al., 2012)

Spiritual activities have been found to be useful in dealing with loneliness, anxiety and depression in older people. Active participation in spiritual activities has been reported to reduce feelings of loneliness in 1791 participants, comprising Malays, Chinese, Indians and other Indigenous groups aged 60 years and over (Teh $e t$ al., 2014). Further, encouraging older people to practise spiritual activities has been demonstrated to weaken the relationship between loneliness and depression (Han and Richardson, 2010). Kim et al. (2014) similarly studied 157 older people and their caregivers in Korea. It was found that people with high levels of spirituality could identify the purpose of their life, and this in turn reduced depression. Khairudin et al. (2011), in a study in Malaysia, found that among older people with anxiety, non-Malays who were less spiritual reported higher levels of anxiety than Malays (who were considered as highly spiritual). These authors suggested that those with high spiritual levels used spiritual beliefs as a coping strategy for anxiety. The benefits of including a spiritual element in RT is obvious and could be of even greater significance for older people dealing with loneliness, anxiety and depression.

Therefore, the adaptation of spirituality in RT may be valuable in both the acceptability of RT in this population, and in helping to understand the mechanism of RT. The integration of spirituality in RT is known as spiritual reminiscence therapy (SRT). The difference between RT and SRT is that, for the latter, the process of sharing memories is guided by a spiritual element, with the purpose to find the meaning of life from the memories that are shared. SRT involves evaluation of life experiences by sharing memories with others that guide individuals to understand the purpose of their life and future hopes (Emery, 2002, Mackinlay and Trevitt, 2010). It also involves the integration of their life stories with their spiritual life journey as an individual and with their family, community and God (MacKinlay, 2006). The effectiveness of SRT more specifically for this population also 
needs greater interrogation before this intervention can be recommended. Therefore, the objective of this paper is to review literature related to spiritual reminiscence therapy for older people with mental health problems.

\section{Methodology}

An integrative review of the literature was conducted to explore this question. The search involved published and unpublished studies using the keywords: spiritual reminiscence OR spiritual life review OR religious life review OR spiritual therapies. The search strategy resulted in 847 studies from the electronic databases of Medline (573), CINAHL (216) and PsycINFO (58). Reference lists of retrieved articles were read to identify additional studies eligible for inclusion; however, no relevant studies were found. The search was limited to studies published in English from 2000 to 2017 to capture the most current time period for the context of this study. Studies were included if they employed or developed SRT. The review excluded studies that did not mention spiritual or religious elements in SRT. Of the 847 studies, five met the inclusion criteria. The reasons for excluding 842 studies were: duplicates studies, book review; not available as a full-text article; or did not use a spiritual element in the reminiscence/ life review therapy (Figure 1).

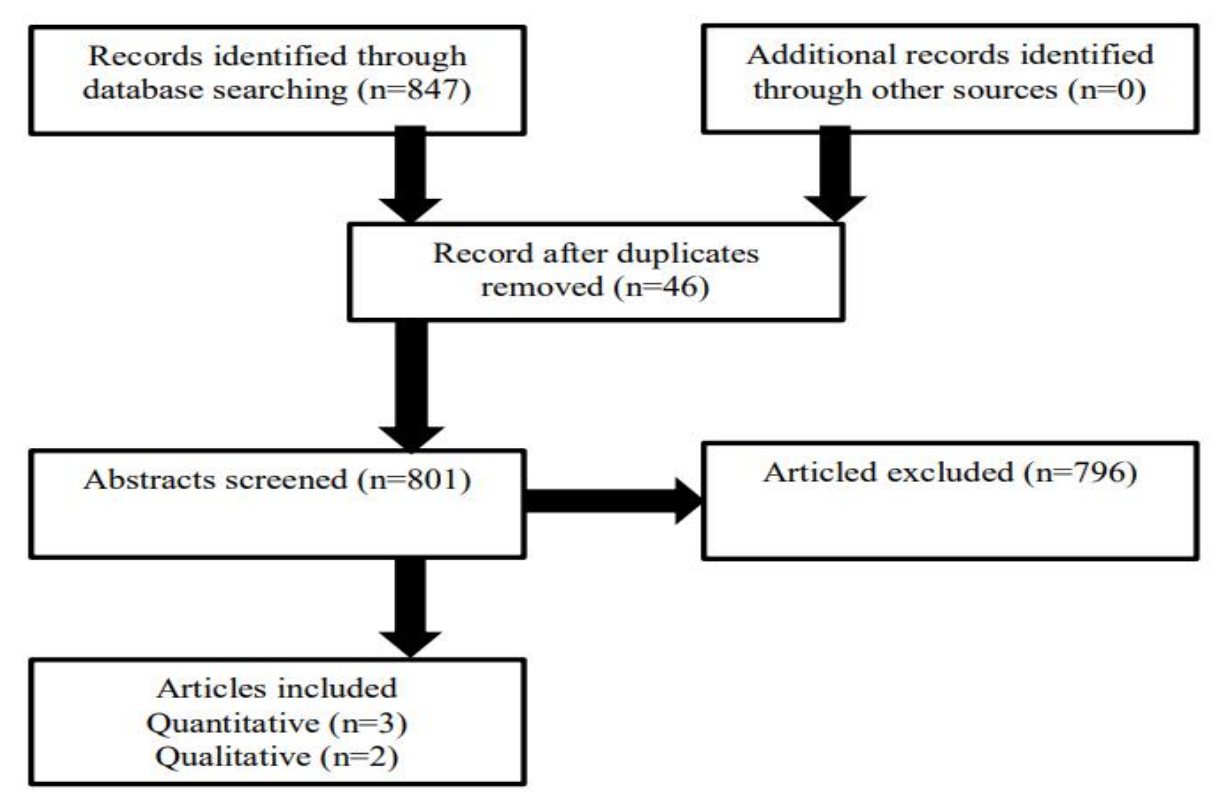

Figure 1 Modified PRISMA flow diagram of article screening and selection for spiritual reminiscence therapy

\section{Results}

Of the five SRT studies selected (Table 1), four were published and one was unpublished. Although Haslam et al. (2013) did not identify their study as SRT, they implemented a religious element in RT (religious song RT). Out of these five studies, three were quantitative studies, and two were qualitative studies. The quantitative studies measured different outcomes: anxiety, depression, hope, life satisfaction, spiritual wellbeing, meaning, social support, personal growth, self-acceptance and spiritual support. The qualitative studies involved older people with dementia. The majority of studies were conducted in Western countries: one in the United States of America (Emery, 2002) and three in Australia (Haslam et al., 2013, MacKinlay, 2009, Mackinlay and Trevitt, 2010). One study involved Taiwanese older people with traditional folk religion in Taiwan (Wu and Koo, 2015). The majority of participants were Caucasian and Christian. The program durations were from six to eight weeks. Program details including themes addressed were reported in four studies (Emery, 2002, MacKinlay, 2009, Mackinlay and Trevitt, 2010, Wu and Koo, 2015). Haslam et al. (2013) did not provide program information. 
Three studies used a program developed and tested by MacKinlay and Trevitt in 2006 (MacKinlay, 2009, Mackinlay and Trevitt, 2010, Wu and Koo, 2015). 
Table 1 Characteristics of spiritual reminiscence therapy studies for older people

\begin{tabular}{|c|c|c|c|c|c|c|c|c|}
\hline Authors & Population/Religion & $\begin{array}{l}\text { Study } \\
\text { design }\end{array}$ & $\begin{array}{l}\text { Types } \\
\text { of SRT }\end{array}$ & Duration & Theories & Program details & Measurement & Results \\
\hline Emery (2002) & $\begin{array}{l}\text { United States of } \\
\text { America/Caucasians/ } \\
\text { Christians }\end{array}$ & $\begin{array}{l}\text { Quantitative } \\
\text { (Quasi- } \\
\text { experimenta } \\
\text { 1) }\end{array}$ & $\begin{array}{l}\text { Story } \\
\text { based }\end{array}$ & 8 weeks & $\begin{array}{l}\text { Erikson's } \\
\text { theory }\end{array}$ & $\begin{array}{l}\text { Self-developed } \\
\text { Week 1: First } \\
\text { Week 2: School Days } \\
\text { Week 3: Life Work } \\
\text { Week 4: Traditions } \\
\text { Week 5: Battles Won \& } \\
\text { Lost } \\
\text { Week 6: Turning points } \\
\text { Week 7: Then \& Now } \\
\text { Week 8: Words of Wisdom }\end{array}$ & $\begin{array}{l}\text { ERC, GDS, } \\
\text { PG, PLI, } \\
\text { PWB, R- } \\
\text { COPE, SNI, } \\
\text { STAI }\end{array}$ & $\begin{array}{l}\text { No significant improvement on } \\
\text { measures of depression }(p= \\
0.62) \text {, anxiety }(p=0.28) \text { and self- } \\
\text { acceptance }(p=0.52) \\
\text { SRT group reported more } \\
\text { personal growth }(p=0.01) \text {, } \\
\text { spiritual support }(p=0.04) \text {, and } \\
\text { purpose in life }(p<0.05)\end{array}$ \\
\hline $\begin{array}{l}\text { Haslam et al. } \\
\text { (2013) }\end{array}$ & $\begin{array}{l}\text { Australia/ } \\
\text { Caucasians/Christians }\end{array}$ & $\begin{array}{l}\text { Quantitative } \\
\text { (Randomise } \\
\text { d controlled } \\
\text { trial) }\end{array}$ & $\begin{array}{l}\text { Song } \\
\text { and } \\
\text { story } \\
\text { based }\end{array}$ & $\begin{array}{l}6 \text { weeks } \\
{[12} \\
\text { sessions, } \\
\text { two per } \\
\text { week] }\end{array}$ & $\begin{array}{l}\text { Religion } \\
\text { identity and } \\
\text { Social } \\
\text { identity } \\
\text { theory }\end{array}$ & No information included & $\begin{array}{l}\text { GAI, ICC, } \\
\text { IRG, RI, } \\
\text { SAGE, SLS }\end{array}$ & 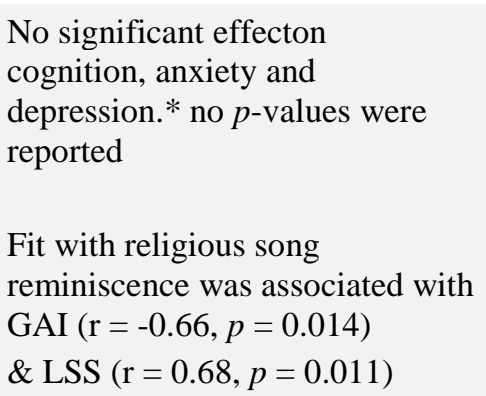 \\
\hline $\begin{array}{l}\text { Wu and Koo } \\
(2015)\end{array}$ & $\begin{array}{l}\text { Taiwan/ } \\
\text { Taiwanese/Traditional } \\
\text { folk religion }\end{array}$ & $\begin{array}{l}\text { Quantitative } \\
\text { (Randomise } \\
\text { d controlled } \\
\text { trial) }\end{array}$ & $\begin{array}{l}\text { Story } \\
\text { based }\end{array}$ & 6 weeks & $\begin{array}{l}\text { Erikson's } \\
\text { theory and } \\
\text { Continuity } \\
\text { theory }\end{array}$ & $\begin{array}{l}\text { SRT program established by } \\
\text { MacKinlay and Trevitt } \\
\text { (2006) } \\
\text { Week 1: Life meaning } \\
\text { Week 2: Relationships, } \\
\text { isolation and connecting } \\
\text { Week 3: Hope, fears, and } \\
\text { worries } \\
\text { Week 4: Growing older and } \\
\text { transcendence }\end{array}$ & $\begin{array}{l}\text { HHI, LSS, } \\
\text { MMSE, SIWB }\end{array}$ & $\begin{array}{l}\text { Improved hope }(p=0.005), \text { life } \\
\text { satisfaction }(p<0.001) \text { and } \\
\text { spiritual well-being }(p=0.001)\end{array}$ \\
\hline
\end{tabular}




\begin{tabular}{|c|c|c|c|c|c|c|c|c|}
\hline & & & & & & $\begin{array}{l}\text { Week 5: Spiritual and } \\
\text { religious beliefs } \\
\text { Week 6: Spiritual and } \\
\text { religious practices }\end{array}$ & & \\
\hline $\begin{array}{l}\text { MacKinlay } \\
(2009)\end{array}$ & $\begin{array}{l}\text { Australia/Latvian/No } \\
\text { information on religion }\end{array}$ & Qualitative & $\begin{array}{l}\text { Story } \\
\text { based }\end{array}$ & 6 weeks & - & $\begin{array}{l}\text { SRT established by } \\
\text { MacKinlay and Trevitt } \\
\text { (2006) }\end{array}$ & - & $\begin{array}{l}\text { Eight themes were } \\
\text { connectedness, spiritual and } \\
\text { religious practices, vulnerability } \\
\text { and transcendence, physical } \\
\text { health issues, wisdom and } \\
\text { memory, war experiences, } \\
\text { hope/fear and communication } \\
\text { style of facilitator }\end{array}$ \\
\hline $\begin{array}{l}\text { Mackinlay and } \\
\text { Trevitt (2010) }\end{array}$ & $\begin{array}{l}\text { Australia / } \\
\text { Caucasian/Christians }\end{array}$ & Qualitative & $\begin{array}{l}\text { Story } \\
\text { based }\end{array}$ & 6 weeks & $\begin{array}{l}\text { Erikson's } \\
\text { theory }\end{array}$ & $\begin{array}{l}\text { SRT established by } \\
\text { MacKinlay and Trevitt } \\
\text { (2006) }\end{array}$ & - & $\begin{array}{l}\text { Two themes revealed 'meaning } \\
\text { in life' and 'vulnerability and } \\
\text { transcendence' }\end{array}$ \\
\hline
\end{tabular}

Note: ERC: Elder Role Checklist; GAI: Geriatric Anxiety Inventory; GDS: Geriatric Depression Scale-30 items; HHI: Herth Hope Index; ICC: Identification with care community; IRG: Identification with reminiscence group; LSS: Life Satisfaction Scale; MMSE: Mini Mental State Examination; PG: Personal Growth; PLI: Purpose in Life Index; PWB: Psychological Wellbeing Inventory; R-COPE: Religious Coping Activity Scales; RI: Religious identity; SAGE: Self-Administered Gerocognitive Examination; SNI: Social Network Inventory; SIWB: Spirituality Index of Wellbeing; SLS: Satisfaction with Life Scale; SRT: Spiritual reminiscence therapy; STAI: State-trait anxiety inventory 


\section{Discussion}

The evidence regarding the effectiveness of SRT was limited. Only one previous SRT study has been conducted among older people with anxiety and depression, but the result was not significant (Emery, 2002). Additionally, it was conducted almost 15 years ago. Participants were not screened for anxiety and depression before the recruitment, and the study was quasi-experimental, with no randomisation. Haslam et al.'s (2013) study investigating the effectiveness of religious song-based RT compared with secular-song based RT and storybased RT found no significant effect for anxiety, although those in the religious identity group had reduced anxiety levels. This demonstrated that religious integration in RT may have some usefulness for older people with anxiety.

In relation to other outcomes, a recent study by Wu and Koo (2015) implemented a SRT program among 103 older people with mild to moderate dementia in a Taiwanese Hospital, producing significant findings for hope, life satisfaction and spiritual wellbeing. The SRT programs used in these three studies emphasised the sense of "connectedness" that is important for older people to improve their wellbeing (MacKinlay, 2009, Mackinlay and Trevitt, 2010, Wu and Koo, 2015). The qualitative results of previous SRT studies supported the notion that SRT guided older people to find meaning in their life (MacKinlay, 2009, Mackinlay and Trevitt, 2010). MacKinlay (2009) explored the shared life stories of three older Latvian people living in Australia during SRT sessions. The results found that connectedness and spiritual practices were among the themes revealed from the older people's experiences of SRT. Mackinlay and Trevitt (2010) qualitative study involving 113 participants with dementia identified two themes which were 'the meaning in life' and 'vulnerability and transcendence', suggesting that SRT provides meaningful connection among participants in SRT. Despite limited evidence from the quantitative findings, the qualitative findings suggested that SRT can be a worthwhile intervention for older people.

The inconsistent use of theoretical underpinnings in SRT such as Erikson's theory, continuity theory and social identity theory may limit our understanding. There are no specific theories for SRT and the approaches vary between studies. Erikson's (1963) developmental theory concentrated on the development of the ego-integrity state. According to this approach, older people consequently feel satisfied with their life experiences and prepared for unexpected things that might yet occur. However, Emery (2002) used Erikson's theory to guide SRT and found no significant effect for anxiety and depression. Although there was some description of this theory in Emery's study, there was no link made between Erikson's theory and the findings, limiting the ability to develop an understanding of the mechanism of ego-integrity development in this intervention.

In comparison to Emery's (2002) study, Wu and Koo (2015) described several theories in relation to SRT. These theories included Erikson's theory and continuity theory. Continuity theory, developed by Butler (1963), posited that the reminiscence process guides people to adjust themselves to the changes that happen in their life. This theory suggests that the ability to adapt to changes in their life influences the present characteristics of individuals. Wu and Koo (2015) found significant findings for life satisfaction, hope and spiritual wellbeing. However, there was limited description about the mechanism of SRT from these two theoretical perspectives. Furthermore, the use of continuity theory in the study conducted by Wu and Koo (2015) did not focus on mental health problems.

While no studies have yet specifically explored the mechanism of SRT through this theoretical lens using the concept of spirituality more broadly, Haslam et al. (2013) used religious identity as an extension of social identity. Haslam et al. (2013) argued that group identification through religious song RT was enhanced by religious identity and group identification was negatively correlated with anxiety. 


\section{Conclusion}

To date, no studies have measured the effectiveness of SRT for loneliness; therefore, research is required to determine the effectiveness of this intervention. Interventions that address these three mental health problems together could be of great benefit. Therefore, there is a need in future research to further understand SRT as an intervention for interrelated mental health problems such as loneliness, anxiety and depression.

\section{References}

Abolfathi Momtaz, Y., Hamid, T. A., Ibrahim, R., Yahaya, N. \& Abdullah, S. S., 2012, Moderating effect of Islamic religiosity on the relationship between chronic medical conditions and psychological well-being among elderly Malays.Psychogeriatrics, 12, 43-53.

Amzat, I. H. \& Jayawardena, P., 2016, Emotional Loneliness and Coping Strategies: A Reference to Older Malaysians at Nursing Homes.Journal of Population Ageing, 9, 227-247.

Bulechek, G. M., Butcher, H. K. \& Dochterman, J. M., 2008,Nursing Intervention Classification (NIC).St Louis, Mosby.

Conway, M. A. \& Pleydell-Pearce, C. W., 2000, The construction of autobiographical memories in the selfmemory system. Psychological Review, 107, 261-88.

Coupland, C., Dhiman, P., Morriss, R., Arthur, A., Barton, G. \& Hippisley-Cox, J., 2011, Antidepressant use and risk of adverse outcomes in older people: population based cohort study.British Medical Journal 343.

Emery, E. E., 2002,Living history-spiritually...or not? A comparison of conventional and spiritually integrated reminiscence groups. PhD, Bowling Green State University.

Flint, A. J., 2005, Generalised anxiety disorder in elderly patients : epidemiology, diagnosis and treatment options.Drugs Aging, 22, 101-14.

Frazer, C. J., Christensen, H. \& Griffiths, K. M., 2005, Effectiveness of treatments for depression in older people. The Medical Journal of Australia, 182, 627-32.

Han, J. \& Richardson, V. E., 2010, The Relationship Between Depression and Loneliness Among Homebound Older Persons: Does Spirituality Moderate This Relationship? Journal of Religion \& Spirituality in Social Work: Social Thought, 29, 218-236.

Haque, A., 2008, Culture-bound syndromes and healing practices in Malaysia. Mental Health, Religion \& Culture, 11, 685-696.

Harris, J. L., 199, Reminiscence: A Culturally and Developmentally Appropriate Language Intervention for Older Adults. American Journal of Speech-Language Pathology, 6, 19-25.

Haslam, C., Haslam, S. A., Ysseldyk, R., Mccloskey, L., Pfisterer, K. \& Brown, S. G., 2013, Social identification moderates cognitive health and well-being following story- and song-based reminiscence. Aging \& Mental Health, 18, 425-434.

Ibrahim, N., 2014, Depression and factors of psychological well-being among Malay, Chinese and Indian elderly women at Rumah Seri Kenangan (RSK), public welfare institutions in Malaysia. Ph.D, Southern Illinois University at Carbondale.

Khairudin, R., Nasir, R., Zainah, A. Z., Fatimah, Y. \& Fatimah, O., 2011, Depression, Anxiety and Locus of Control among Elderly with Dementia. Pertanika Journal of Social Sciences \& Humanities, 19, $27-31$.

Kim, S. S., Hayward, R. D. \& Reed, P. G., 2014, Self-transcendence, spiritual perspective, and sense of purpose in family caregiving relationships: a mediated model of depression symptoms in Korean older adults. Aging \& Mental Health, 1-9.

Koenig, H. G., King, D. E. \& Carson, V. B., 2012,Handbook of religion and health Oxford, Oxford University Press.

Koenig, H. G., Mccullough, M. E. \& Larson, D. B., 2001,Handbook of religion and health, Oxford, New York, New York : Oxford University Press.

Lindsey, P. L., 2009, Psychotropic Medication Use among Older Adults: What All Nurses Need to Know. Journal of Gerontological Nursing, 35, 28-38. 
Mackinlay, E., 2006,Spiritual growth and care in the fourth age of life / Elizabeth MacKinlay, Philadelphia, Philadelphia : Jessica Kingsley Publishers.

Mackinlay, E., 2009, Using Spiritual Reminiscence with a Small Group of Latvian Residents with Dementia in a Nursing Home: A Multifaith and Multicultural Perspective. Journal of Religion, Spirituality \& Aging, 21, 318329.

Mackinlay, E. \& Trevitt, C., 2006,Facilitating spiritual reminiscence for older people with dementia a learning package, New South Wales, National Library of Australia Catalogue in Publication Data.

Mackinlay, E. \& Trevitt, C., 2010, Living in aged care: using spiritual reminiscence to enhance meaning in life for those with dementia. International Journal of Mental Health Nursing, 19, 394-401.

Mackinlay, E. \& Trevitt, C., 2012,Finding Meaning in the Experience of Dementia : The Place of Spiritual Reminiscence Work, London, Jessica Kingsley Publishers.

Muhamad, M. \& Merriam, S. B, Aging and learning in a non-western culture: The case of Malaysia. Proceedings of the 41 st Annual Adult Education Research Conference, 2000. 287-291.

Razali, S. M., Aminah, K. \& Khan, U. A., 2002, Religious-Cultural Psychotherapy in the Management of Anxiety Patients. Transcultural Psychiatry, 39, 130-136.

Stanley, M. A., Bush, A. L., Camp, M. E., Jameson, J. P., Phillips, L. L., Barber, C. R., Zeno, D., Lomax, J. W. \& Cully, J. A., 2011, Older adults' preferences for religion/spirituality in treatment for anxiety and depression. Aging \& Mental Health, 15, 334-343.

Syed Akil, S. M. \& Abdullah, S., Understanding life at the old folks home The 2015 WEI Internationa; Academic Conference Proceedings, 2015 Vienna, Austria. The West East Institute.

Teh, J. K. L., Tey, N. P. \& Ng, S. T., 2014, Family support and loneliness among older persons in multiethnic Malaysia. The Scientific World Journal, 2014, 654382.

Webster, J. D., Bohlmeijer, E. T. \& Westerhof, G. J., 2010, Mapping the Future of Reminiscence: A Conceptual Guide for Research and Practice. Research on Aging, 32, 527-564.

Wilson, K., Mottram, P. G., Sivananthan, A. \& Nightingale, A., 2001, Antidepressants versus placebo for the depressed elderly. Cochrane Database of Systematic Reviews.

Wu, L. F. \& Koo, M., 2015, Randomized controlled trial of a six-week spiritual reminiscence intervention on hope, life satisfaction, and spiritual well-being in elderly with mild and moderate dementia. International Journal of Geriatric Psychiatry. 